\title{
A Growth Curve Analysis of Mandatory Student Athletics Fees
}

\author{
Willis A. Jones, Michael J. Rudolph, and Michael Brown \\ University of Kentucky
}

This study used growth curve modeling to estimate the growth trajectory of mandatory student athletics fees at public NCAA Division I universities from 2004-2016. We specifically focused on three measures of athletics fees; total athletics fees, athletics fees per FTE, and athletics fees as a percentage of total student costs. We found that in general the growth trajectory of athletics fees was positive, but that the rate of growth has declined over the years. We also found that on average less than $5 \%$ of student costs are directly attributable to athletics fees and that the growth trajectory of athletics fees differs significantly based on NCAA Division I subdivision affiliation. These findings have implications for policymakers and commentators interested in the role athletics fees play in college student costs.

Keywords: growth modeling, college costs, SEM, student fees

The costs of being a student is an important policy issue within higher education. With costs increasing and students in greater debt than ever before, college tuition and fees are increasingly being scrutinized by students, parents, and state legislators. One such fee that has come under intense scrutiny in recent years is student athletics fees (henceforth called athletics fees). Athletics fees are mandatory fees assessed to students which are used to support intercollegiate athletics (USA Today Sports, 2017). According to the 2016 National Collegiate Athletic Association (NCAA) athletic department revenue database, $82 \%$ of public NCAA Division I institutions collected athletics fees from students during the 2015-2016 academic year.

Some argue that because athletics fees are often hidden within general fees, students lack knowledge of athletics fees and are therefore not fully informed on how their tuition and fees are being used (Denhart \& Ridpath, 2011; Lapan, 2016; Rosenstein, 2017). In 2015, the state of Virginia passed a bill which prohibits athletics fees used to support intercollegiate athletics programs from exceeding a certain percentage of athletics revenues at 4-year public institutions of higher education in the state. The impetus for this bill was the belief that athletics fees

Jones, Rudolph, and Brown are with the University of Kentucky, Lexington, KY. Address author correspondence to Willis Jones at willis.a.jones@uky.edu. 
had been one of the major drivers behind a $122 \%$ increase in tuition and fees since 2002 in Virginia (Minium, 2015). In 2016, the University System of Georgia capped how much a public university's athletics budget can rely on student fees (Kingkade, 2016).

There are several anecdotal stories of students paying high athletics fees found in popular press. Kingkade (2012) notes that students at Rutgers University and Washington State University each pay around nearly $\$ 1,000$ per year in fees to support athletics. Minium (2015) reported that, in Virginia, several public institutions charge students over $\$ 1,000$ per year in athletics fees. Are these anecdotal stories the norm across higher education institutions? Are athletics fees a substantial portion of student costs? These are questions our study looked to answer. This study used latent growth curve analysis to explore the absolute and relative growth of athletics fees among public NCAA Division I universities. More specifically, our study addressed the following research questions:

- Among public NCAA Division I institutions, what has been the growth trajectory of total athletics fees from 2004-2016?

- Among public NCAA Division I institutions, what has been the growth trajectory of athletics fees per student from 2004-2016?

- Among public NCAA Division I institutions, what has been the growth trajectory of athletics fees per student as a percentage of student costs from 2004-2016?

- Among public NCAA Division I institutions, are initial levels of athletics fees or growth in athletics fees correlated with Division I subdivision affiliation?

The following section of the paper provides a literature review on the role of athletics fees in athletic department budgeting and student costs. This is followed by a description of the methods used in the study and the research findings. The paper concludes with a discussion of the implications of our findings and suggestions for future research.

\section{Literature Review}

The use of mandatory student fees to support intercollegiate athletics is not a new phenomenon. Thelin (2000) notes that athletic budgets, especially budgets for men's teams, "had long benefitted from receiving the proceeds of mandatory student fees" (p. 395). In a 1986 survey by the American Association of State Colleges and Universities, it was found that athletics fees accounted for $51 \%$ of athletic department revenue at Division I universities (Thelin \& Wiseman, 1990).

Though the use of student tuition and fees to support athletics has been a point of contentious discussion dating back to 1940 (Thelin \& Wiseman, 1990), the rapidly rising cost of higher education in the past 20 years has led to greater attention on athletics fees. Much of what has been written about athletics fees has come from popular media outlets. Newspapers are littered with stories about institutional referendums to increase or decrease athletics fees, the role of athletics fees in athletic department budgets, and hypotheses for why athletics fees are increasing. The Chronicle of Higher Education noted initiatives at the University 
of Texas-Arlington, the University of Texas-San Antonio, and California Polytechnic University at San Luis Obispo, where students voted to increase their mandatory fees to support athletics (Suggs, 2004). USA Today tells the story of several schools, such as Radford University, Towson University, and the University of California-Berkeley, engaged in debates about athletics fees (Berkowitz, Upton, McCarthy, \& Gillum, 2010). US News and World Reports tells the story of students at the University of California-Santa Cruz working to block a $\$ 270$ increase in athletics fees (Lapan, 2016). The Huffington Post chronicles the story of rising athletics fees at Georgia State University as the school attempted to increase the profile of the university and athletics program (Wolverton, Hallman, Shifflett, \& Kambhampati, 2015). The Washington Post discussed how even "high profile" athletics programs such as Texas A\&M University, University of Kansas, and Clemson University have proposed increasing mandatory athletics fees, often with strong pushback from students (Hobson \& Rich, 2015b). The Arizona Republic said "mandatory fees to fund athletics have been controversial in Arizona", when telling the story of athletics fees being introduced at Arizona State University and the University of Arizona (Ryman, 2017).

Though journalists have been very interested in the topic of athletics fees, empirical scholarship on athletics fees has been much less frequent. In a search of several academic databases, we found little published research or dissertations specifically on mandatory athletics fees. The scholarship we did find can be grouped into four categories. The first category is research on student perceptions of and willingness to pay athletics fees. Ridpath, Smith, Garrett, and Robe (2015) surveyed students at Mid-American Conference universities to find out if students were aware of general student fees and whether students wanted to pay athletics fees. The paper found that while students at these institutions were largely aware of general fees, they were unaware of how the fees were used. Most students did not want to pay as much as they were paying to finance the athletics department.

As part of a doctoral dissertation, Howard (2016) surveyed over 500 students at Florida State University (FSU), asking several questions about the consumption and funding of athletics on their campus. When specifically asked about athletics fees, it was found that only $17 \%$ of students did not want to pay any fees to support athletics. Graduate students were less willing to pay athletics fees relative to undergraduates. Howard also used a regression model to estimate which variables correlated with the willingness of students to pay higher athletics fees at FSU. It was found that males and those students who are active fans of the FSU athletics program were more willing to pay higher athletics fees. Those who supported the use of institutional funds to support college athletics were less likely to be willing to pay higher athletics fees.

A second category of empirical research on athletics fees looks at the relationship between athletics fees and athletics success. Morton (2017) asked whether athletics fees were a good predictor of athletics department on-field success (as measured by the athletics program's Learfield Directors' Cup standings). Using cross-sectional data from public Division I institutions, it was found that student fees were not a significant predictor of Directors' Cup standing.

While not focused exclusively on athletics fees, two studies have attempted to model the variables which most strongly correlate with institutional support to intercollegiate athletics. Denhart and Vedder (2010) did a cross-sectional analysis 
of the relationship between institutional athletics support (combined athletics fees, direct government support to athletics, direct institutional support to athletics, and indirect facilities support to athletics) and various institutional characteristics. Denhart and Vedder found that institutional athletics support was higher at schools with lower enrollments, lower institutional wealth, and higher proportions of low income students. The authors conclude that athletic support constitutes a "regression tax", given that poorer students and institutions typically pay more to support intercollegiate athletics.

Instead of focusing on institutional characteristics like Denhart and Vedder (2010), Kearney (2014) explored the effects that football and men's basketball onfield/court success have on institutional athletics support (again defined as combined athletics fees, direct government support to athletics, direct institutional support to athletics, and indirect facilities support to athletics) for intercollegiate athletics. Using a fixed effects model with instrument variables, Kearney found that, among public Division I institutions, a higher number of basketball wins correlated with increased institutional athletics support the following year. Combined football and basketball success was also correlated with higher institutional athletics support the following year. While football success on its own was not a statistically significant predictor of institutional athletics support, the findings of Kearney's study suggest institutions and students are willing to provide greater support to athletics departments who are successful in high-profile sports.

A final category of research related to athletics fees looks at the impact of these fees on other elements of an institution's budget. In his doctoral dissertation, Rudolph (2017) asked several questions about the relationship between total institutional athletics support and education and related (E\&R) expenditures at public NCAA Division I institutions. Using a fixed effects structural equation model, Rudolph found a small but statistically significant positive relationship between total institutional athletics support and E\&R. Rudolph also looked specifically at the relationship between school funds (direct and indirect institutional support to athletics) and E\&R, but a statistically significant relationship was not found. Athletics fees were not examined specifically in the Rudolph study.

The current study looked to contribute to this developing line of research on athletics fees. While the aforementioned research papers and news stories offer important information about athletics fees, there remains a need for further empirical research to gain a fuller understanding of the trajectory of athletics fees, the size of athletics fees relative to overall student costs, and whether athletics fees have grown differently across institutional types. This information can help inform policies at the state and institutional level (such as those from Virginia and Georgia) looking to limit athletics fees. This information can also help lead to a more accurate analysis of the role athletics fees play in overall student costs.

\section{Data and Empirical Methodology}

Data for this study was collected from the USA Today College Athletics Finance database. Every year since the 2004-2005 academic year (AY), USA Today has sent public records requests to state-supported institutions of higher education competing at the NCAA Division I level asking for detailed athletics-related 
financial information, ranging from ticket sales revenue to game-day expenses. From this dataset, we obtained data on per year total athletics fees received by athletics departments. Because USA Today sends record requests to public NCAA Division I universities only, our sample was limited to those institutions. A total of 230 universities submitted at least 1 year of data to the USA Today database.

Additional data for this study were obtained from the Integrated Postsecondary Data System (IPEDS) administered by the United States Department of Education. Each year, IPEDS collects institutional data in various areas, including institutional characteristics, institutional prices, and enrollment. To calculate a measure of athletics fees per student for this study, full-time equivalent (FTE) student enrollment from AY 2004-2005 through AY 2015-2016 were collected from IPEDS. According to the IPEDS Data Glossary, the FTE of the institution's part-time enrollment is estimated by multiplying each part-time undergraduate by a factor of .404 and each part-time graduate student by a factor of .362. These numbers are then added to the full-time enrollment headcounts to obtain total FTE enrollment. Total athletics fees was divided by total FTE to obtain our measure of athletics fees per FTE.

A goal of this study was to examine the growth of per student athletics fees as a percentage of overall student costs. To do this, we first obtained IPEDS data on institutional per year net tuition revenue from AY 2004-2005 through AY 20152016. IPEDS defines net tuition revenue as all tuition and fees assessed against students' net of refunds and discounts (such as scholarships or fellowships). We took this net tuition revenue variable and divided it by FTE to obtain a measure of student tuition and fees per FTE. While IPEDS provides other measures of student costs per year (such as average net price for first time undergraduates or published tuition/fees), these other measures have significant shortcomings with regard to our study. For example, some student cost measures in IPEDS do not account for tuition discounting, while others fail to simultaneously measure graduate and undergraduate student costs. While there are certainly shortcomings to our student tuition and fees per FTE variable, we believe it offers a good measure of what students each year paid out of pocket to attend an institution of higher education. To calculate athletics fees as a percentage of overall student costs, we divided athletics fees per FTE by student tuition and fees per FTE.

The final variable obtained for this study was NCAA Division I subdivision affiliation. There are three subdivisions within Division I. Universities in the Football Bowl Subdivision (FBS) are those with football teams that participate in bowl games. Universities in the Football Championship Subdivision (FCS) are those with football teams that participate in the NCAA-run football championship playoff. Division I-no football are universities which do not sponsor intercollegiate football. Costs and revenue structures for athletics within each subdivision are very different. According to the NCAA Division I Intercollegiate Athletics Program Report, median total expenses on athletics in 2014 were $\$ 63$ million for FBS universities, \$15 million for FCS universities, and \$14 million for Division I-no football universities (Fulks, 2015). Athletics programs are also supported very differently based on Division I subdivision. In 2014, $20 \%$ of athletics revenue at FBS universities was allocated revenue coming from outside the athletics department. At FCS universities that number was $71 \%$ and it was $76 \%$ at Division I-no football universities (Fulks, 2015). 
Given these differences in costs and allocated revenue, it is reasonable to believe that the growth of athletics fees would be different based on Division I subdivision affiliation. To test this in our study, we used data from the Equity in Athletics Disclosure Act (EADA) to group our sample into NCAA Division I affiliation categories. This created an identification challenge because of institutional transition between NCAA division and subdivision levels. Just under $90 \%$ of the institutions in our sample remained in the same NCAA Division I subdivision from 2005-2016. The remaining universities changed Division I subdivision or division level during the time period studied. Because this constitutes a relatively small amount of variation in this variable, we treated NCAA affiliation category as a time-invariant characteristic in our growth curve models. We grouped institutions into seven categories: (1) FBS for entire study period (42\% of sample), (2) FCS for entire study period (30\% of sample), (3) Division I-no football for entire study period (17\% of sample), (4) universities which started study period in the FCS and later transitioned to the FBS (2\% of sample), (5) universities which started study period at Division I-no football level and later added either FBS- or FCS-level football (3\% of sample), (6) universities which started study period at the NCAA Division II with football level and later transitioned to FBS or FCS ( $2 \%$ of sample), and (7) universities which started study period at NCAA Division II-no football level and later transitioned to Division I-no football (3.5\% of sample). We also had to deal with the unique case of the University of Alabama-Birmingham (UAB). UAB was one of the FBS universities that dropped football for 2015-2016. The team, however, was quickly reestablished the next year and resumed play in the FBS for 2017-2018. We treated UAB as FBS for the entire time period in this study.

Data collected for this study were examined using growth curve modeling (GCM). GCM is a set of analytic techniques that allow a researcher to take observed repeated observations and make an inference about the existence of a growth trajectory within the data. GCM can be valuable for analyzing longitudinal data because it explicitly models the shape of trajectories across individual subjects over time and how those trajectories vary both systematically and randomly (RabeHesketh \& Skrondal, 2008). For this study, universities were treated as individual subjects, with yearly observations of athletics fees treated as the repeated measures. We were interested in investigating the course of athletics fees changes over time, how this course of change differed across institutions, and whether NCAA affiliation level was a significant predictor of this course of change.

GCM is traditionally done using either structural equation modeling or multilevel modeling. Given the characteristics of our data, particularly its high amount of variability, we decided to do our GCM using the multilevel framework. With multilevel models it is assumed that data is in a nested structure. In our study, yearly student fee observations are nested within institutions. To execute this model, we first fit a level 1 regression model of the following form:

$$
\text { Stud Fees }{ }_{\mathrm{ti}}=\beta_{\mathrm{oi}}+\beta_{1 \mathrm{i}} \text { Year }_{\mathrm{ti}}+\varepsilon_{\mathrm{ti}}
$$

where Stud Fees ${ }_{\mathrm{ti}}$ is student fees charged in time period $(t)$ at the institution $(i), \beta_{\mathrm{oi}}$ is the intercept for each institution's trajectory, $\beta_{1 \mathrm{i}}$ is the slope of each institution's trajectory as a function of time, and $\varepsilon_{\mathrm{ti}}$ is a residual. This equation represents the predicted growth trajectory for each individual institution in our dataset. We then 
estimated a set of level 2 equations to identify between institutional variance in intercept and slope from the level 1 model:

$$
\begin{aligned}
& \beta_{\mathrm{oi}}=\gamma_{00}+r_{0 \mathrm{i}} \\
& \beta_{1 \mathrm{i}}=\gamma_{10}+r_{1 \mathrm{i}}
\end{aligned}
$$

where $\gamma$ represents the means of each institution's trajectory and $r$ is a residual. Combining the level 1 and level 2 models produces the following reduced-form model:

$$
\begin{aligned}
\text { Stud Fees }_{\mathrm{ti}} & =\gamma_{00}+\mathrm{r}_{0 \mathrm{i}}+\left(\gamma_{10}+\mathrm{r}_{1 \mathrm{i}}\right) \text { Year }_{\mathrm{ti}}+\varepsilon_{\mathrm{ti}} \\
& =\gamma_{00}+\gamma_{10} \text { Year }_{\mathrm{ti}}+\mathrm{r}_{0 \mathrm{i}}+\mathrm{r}_{1 \mathrm{i}} \text { Year }_{\mathrm{ti}}+\varepsilon_{\mathrm{ti}}
\end{aligned}
$$

This reduced-form equation provides a fixed estimation (which captures the mean trajectory in our data) and a random effect (which captures the between and within institutional variation from the fixed effect). To account for inflation, estimation models were run using consumer price index (CPI) adjusted financial data (values were scaled to 2005 dollars).

\section{Study Findings}

Of the 230 institutions which submitted at least 1 year of data to the USA Today database from 2004-2016, four were dropped. The United States Military Academy (Army), Kennesaw State University, University of Delaware, and Pennsylvania State University failed to provide IPEDS with tuition and fee data over the time period studied. Descriptive statistics for the remaining 226 universities can be found in Tables 1-3. Table 1 explores variable variation at both level 1 and level 2 of the data. The overall mean amount of total athletics fees collected by institutions in our sample was just over $\$ 3.5$ million per year, with a standard deviation of

\section{Table 1 Descriptive Stats}

\begin{tabular}{lccc}
\hline Variables & Mean & SD & Observation \\
\hline $\begin{array}{l}\text { Total athletics fees } \\
\text { Overall }\end{array}$ & $\$ 3,515,897$ & $\$ 3,790,354$ & $\mathrm{~N}=2668$ \\
$\quad$ Between & & $\$ 3,583,221$ & $\mathrm{~N}=226$ \\
$\quad$ Within & $\$ 1,239,944$ & $\mathrm{~T}-\mathrm{bar}=11.81$ \\
Athletics fees per FTE & & $\$ 260$ & $\mathrm{~N}=2668$ \\
Overall & $\$ 242$ & $\$ 248$ & $\mathrm{~N}=226$ \\
Between & & $\$ 77$ & $\mathrm{~T}-\mathrm{bar}=11.81$ \\
Within & & .057 & $\mathrm{~N}=2667$ \\
Athletics fees \% of costs & .047 & .055 & $\mathrm{~N}=226$ \\
Overall & & .017 & $\mathrm{~T}-\mathrm{bar}=11.80$ \\
Between & & & \\
Within & & & \\
\hline
\end{tabular}

Abbreviation: FTE $=$ full-time equivalent. 
Table 2 Descriptive Statistics by NCAA Affiliation Group*

\begin{tabular}{lccc}
\hline & $\begin{array}{c}\text { Total Athletics } \\
\text { Fees }\end{array}$ & $\begin{array}{c}\text { Athletics Fees } \\
\text { per FTE }\end{array}$ & $\begin{array}{c}\text { Athletics Fees as a } \\
\text { Percentage of Costs }\end{array}$ \\
\hline FBS & $\$ 3,403,179$ & $\$ 148$ & 0.0246 \\
& $(3,794,011)$ & $(159)$ & $(0.0275)$ \\
FCS & $\$ 2,832,948$ & $\$ 297$ & 0.0600 \\
& $(3,572,829)$ & $(334)$ & $(0.0648)$ \\
DI-NF & $\$ 3,649,136$ & $\$ 289$ & 0.0642 \\
& $(2,952,320)$ & $(227)$ & $(0.124)$ \\
FCS to FBS & $\$ 6,417,501$ & $\$ 310$ & 0.0616 \\
& $(2,590,545)$ & $(90)$ & $(0.0259)$ \\
DI-NF to DI-FB & $\$ 8,931,482$ & $\$ 445$ & 0.0859 \\
& $(6,177,998)$ & $(227)$ & $(0.0595)$ \\
DII-FB to DI-FB & $\$ 4,874,289$ & $\$ 318$ & 0.0598 \\
& $(4,607,028)$ & $(131)$ & $(0.0340)$ \\
DII-NF to DI-NF & $\$ 3,209,238$ & $\$ 451$ & 0.106 \\
& $(1,772,004)$ & $(364)$ & $(0.0776)$ \\
\hline
\end{tabular}

Abbreviations: DI-NF = Division I with no football; DII-FB = Division II with football; DII-NF = Division II with no football; DI-FB = Division I with football; FBS = Football Bowl Subdivision; FCS = Football Championship Subdivision; FTE $=$ full-time equivalent.

*Standard deviations in parentheses.

\section{Table 3 Descriptive Statistics in Select Years*}

\begin{tabular}{lccc}
\hline & AY 2004-2005 & AY 2009-2010 & AY 2014-2015 \\
\hline Total athletics fees & $\$ 2,797,345$ & $\$ 3,547,633$ & $\$ 4,051,452$ \\
& $(2,817,266)$ & $(3,776,821)$ & $(4,393,783)$ \\
Athletics fees per FTE & $\$ 204$ & $\$ 239$ & $\$ 268$ \\
& $(212)$ & $(255)$ & $(284)$ \\
Athletics fees percent of costs & 0.0430 & 0.0495 & 0.0470 \\
& $(0.045)$ & $(0.064)$ & $(0.059)$ \\
\hline
\end{tabular}

Abbreviations: AY = academic year; FTE = full-time equivalent. *Standard deviations in parentheses.

\$3.79 million. Within-institution (year-to-year) standard deviation in total athletics fees was $\$ 1.2$ million, while between-institution standard deviation was $\$ 3.5$ million. Average athletics fees per FTE were \$242, with an overall standard deviation of $\$ 260$, a between-institution standard deviation of $\$ 248$, and a withininstitution standard deviation of $\$ 77$. Mean of athletics fees as a percentage of cost per FTE was $4.7 \%$, with an overall standard deviation of $5.7 \%$, a betweeninstitution standard deviation of 5.5\%, and a within-institution standard deviation of $1.7 \%$. Given the variety of NCAA Division I institutions in our sample, the 
rather large between-institution standard deviations found in Table 1 were somewhat expected.

Tables 2 and 3 display descriptive statistics by NCAA affiliation group and in selected years, respectively. Table 2 shows that FBS universities had lower per FTE athletics fees than FCS and Division I-no football universities. This finding is in line with recent NCAA Division I finance data (Fulks, 2015). Division I-no football universities that added FBS or FCS football and Division II universities with no football that reclassified to Division I-no football had the highest average per FTE athletics fees as well as the highest average athletics fees as a percentage of costs per FTE. Table 3 suggests that total athletics fees and athletics fees per FTE increased in a linear fashion. Athletics fees as a percentage of cost per FTE, however, appear to exhibit more of a curvilinear pattern.

\section{Growth Trajectory of Total Athletics Fees}

We begin by exploring the growth trajectory of total athletics fees received by public NCAA Division I universities. Findings from this analysis are presented in Table 4. Column 1 of Table 4 contains estimates of the unconditional linear growth model exploring the relationship between time and total athletics fees. The constant shows that the model implied value of total athletics fees at the starting point of our data (AY 2004-2005) was \$2.74 million. The linear slope of the trajectory was just over $\$ 135,000$ per year. Both these values were statistically significant.

We then plotted the predicted linear slope of total athletics fees against mean total athletics fees per year to investigate whether a quadratic form better fit the data. This plot suggested that total athletics fees deviated from linearity around 2009, so we fit a GCM which included a quadratic term. The findings of this estimation are presented in column 2 of Table 4 . The data suggest that while total athletics fees increased over the time period studied (as indicated by the positive, statistically significant constant coefficient), the rate of growth declined (as indicated by the negative, statistically significant quadratic term).

In the final column of Table 4 are the findings for our estimation model, which included the time invariant covariate NCAA Division I subdivision affiliation. We wanted to investigate whether the model implied initial value of total athletics fees or the growth trajectory of total athletics fees was significantly different based on subdivision affiliation. To do this, we included a time-by-affiliation interaction term in our GCM. None of the individual dummy variables were statistically significant, which suggests that the model-implied initial value of total athletics fees at FBS universities (the omitted group) is not significantly different than the model-implied initial value of total athletics fees at universities in all other NCAA Division I subdivisions. The time-by-affiliation interaction, however, returned a couple of statistically significant coefficients. The growth trajectory among institutions which transitioned from FCS-level football to FBS-level football was significantly greater than the growth trajectory of FBS-level universities. The growth trajectory among institutions which transitioned from Division I-no football to the FBS- or FCS-level also had a significantly steeper positive growth trajectory than FBS institutions. ${ }^{1}$

Table 4 also contains a measure of the covariance of the variance of the intercept and the slope in our estimation models. This measure provides a linear 


\section{Table 4 Growth Trajectory of Total Athletics Fees}

\begin{tabular}{|c|c|c|c|}
\hline Year & $\begin{array}{c}1.35 \mathrm{e}+05 * * * \\
(17208.743)\end{array}$ & $\begin{array}{l}1.91 \mathrm{e}+05 * * * \\
(23511.716)\end{array}$ & $\begin{array}{l}1.51 \mathrm{e}+05 * * * \\
(28609.892)\end{array}$ \\
\hline Year squared & & $\begin{array}{c}-5053.278 * * * \\
(1449.346)\end{array}$ & $\begin{array}{c}-5074.824 * * * \\
(1449.229)\end{array}$ \\
\hline FCS & & & $\begin{array}{l}-6.18 \mathrm{e}+05 \\
(4.49 \mathrm{e}+05)\end{array}$ \\
\hline DI-NF & & & $\begin{array}{l}-1.53 e+05 \\
(5.38 \mathrm{e}+05)\end{array}$ \\
\hline FCS to FBS & & & $\begin{array}{c}1.44 \mathrm{e}+06 \\
(1.29 \mathrm{e}+06)\end{array}$ \\
\hline DI-NF to DI-FB & & & $\begin{array}{c}2.05 \mathrm{e}+06 \\
(1.19 \mathrm{e}+06)\end{array}$ \\
\hline DII-FB to DI-FB & & & $\begin{array}{c}6.36 \mathrm{e}+05 \\
(1.29 \mathrm{e}+06)\end{array}$ \\
\hline DII-NF to DI-NF & & & $\begin{array}{l}-1.06 \mathrm{e}+06 \\
(1.05 \mathrm{e}+06)\end{array}$ \\
\hline Year*FCS & & & $\begin{array}{c}6348.406 \\
(37073.567)\end{array}$ \\
\hline Year* DI-NF & & & $\begin{array}{c}49245.909 \\
(44632.272)\end{array}$ \\
\hline Year*FCS to FBS & & & $\begin{array}{c}2.85 \mathrm{e}+05^{* *} \\
(1.07 \mathrm{e}+05)\end{array}$ \\
\hline Year*DI-NF to DI-FB & & & $\begin{array}{c}6.33 \mathrm{e}+05^{* * * *} \\
(97952.514)\end{array}$ \\
\hline Year*DII-FB to DI-FB & & & $\begin{array}{c}1.52 \mathrm{e}+05 \\
(1.07 \mathrm{e}+05)\end{array}$ \\
\hline Year*DII-NF to DI-NF & & & $\begin{array}{c}1.08 \mathrm{e}+05 \\
(87720.458)\end{array}$ \\
\hline Constant & $\begin{array}{c}2.74 \mathrm{e}+06 * * * \\
(1.91 \mathrm{e}+05)\end{array}$ & $\begin{array}{c}2.65 \mathrm{e}+06 * * * \\
(1.93 \mathrm{e}+05)\end{array}$ & $\begin{array}{c}2.79 \mathrm{e}+06 * * * \\
(2.89 \mathrm{e}+05)\end{array}$ \\
\hline Covariance slope/intercept & .36 & .36 & .33 \\
\hline Observations & 2668 & 2668 & 2668 \\
\hline
\end{tabular}

Abbreviations: DI-NF = Division I with no football; DII-FB = Division II with football; DII-NF = Division II with no football; DI-FB = Division I with football; FBS = Football Bowl Subdivision; FCS $=$ Football Championship Subdivision .

Note. Standard errors in parentheses. Omitted group: FBS. ${ }^{*} p<.01, * * * p<.001$.

assessment of the relationship between where a university started with regard to athletics fees and the growth of athletics fees. The positive .33 correlation in column 3 suggest that universities with higher initial levels of total athletics fees also have higher growth trajectories. This correlation, however, would be 
considered weak using the Evans (1996) correlation guide. Figure 1 graphs the growth curve of total athletics fees by NCAA subdivision affiliation.

\section{Growth Trajectory of Athletics Fees per FTE}

In Table 5, findings are presented for our estimation of the growth trajectory of athletics fees per FTE. As noted earlier, this variable was calculated by dividing total athletics fees by an institution's FTE student enrollment. This variable provides a measure of how much athletics fees cost for each student attending the university. As noted in column 1 of Table 5, the model-implied value of athletics fees per FTE at the starting point of our data was \$204. Each year, athletics fees per FTE appeared to increase around \$6.40. Both the intercept and the linear slope were statistically significant.

After plotting yearly mean athletics fees per FTE against the predicted linear slope and seeing what appeared to be some deviation from linearity, we fit a GCM which included a quadratic term. As shown in column 2 of Table 5, the quadratic term was negative but not statistically significant. This suggests that athletics fees per FTE does not significantly deviate from a linear pattern.

Column 3 of Table 5 presents growth curve coefficients for athletics fees per FTE when NCAA Division I subdivision affiliation is included as a covariate.

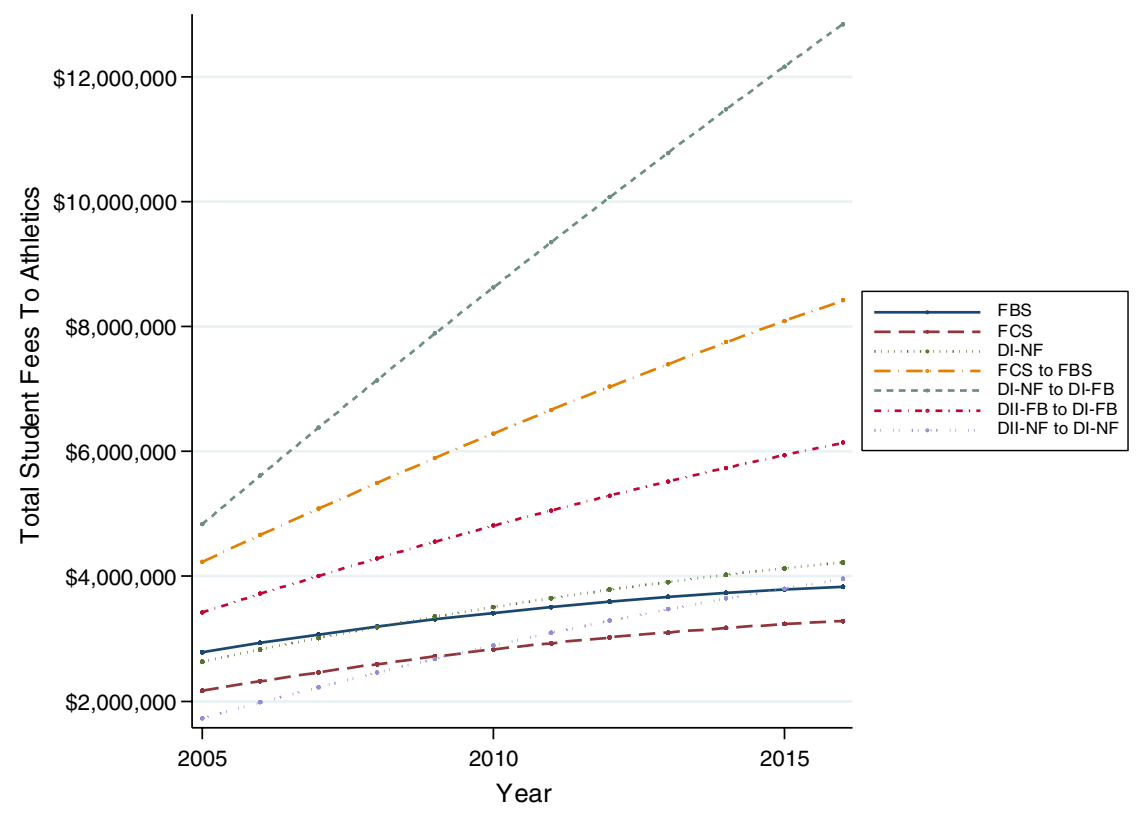

Figure 1 - Growth curves of total athletics fees by NCAA subdivision affiliation. Abbreviations: DI-NF = Division I with no football; DII-FB = Division II with football; DII$\mathrm{NF}=$ Division II with no football; DI-FB = Division I with football; FBS = Football Bowl Subdivision; FCS = Football Championship Subdivision. 


\section{Table 5 Growth Trajectory of Athletics Fees per FTE}

\begin{tabular}{|c|c|c|c|}
\hline Year & $\begin{array}{c}6.406 * * * \\
(1.042)\end{array}$ & $\begin{array}{c}7.368 * * * \\
(1.540)\end{array}$ & $\begin{array}{c}2.258 \\
(1.508)\end{array}$ \\
\hline Year squared & & $\begin{array}{l}-0.087 \\
(0.102)\end{array}$ & \\
\hline FCS & & & $\begin{array}{c}123.357 * * * \\
(33.289)\end{array}$ \\
\hline DI-NF & & & $\begin{array}{l}93.202 * \\
(39.927)\end{array}$ \\
\hline FCS to FBS & & & $\begin{array}{l}116.329 \\
(95.903)\end{array}$ \\
\hline DI-NF to DI-FB & & & $\begin{array}{l}168.333 \\
(87.980)\end{array}$ \\
\hline DII-FB to DI-FB & & & $\begin{array}{l}108.082 \\
(95.903)\end{array}$ \\
\hline DII-NF to DI-NF & & & $\begin{array}{c}176.119 * \\
(78.106)\end{array}$ \\
\hline Year*FCS & & & $\begin{array}{c}4.553 \\
(2.353)\end{array}$ \\
\hline Year* DI-NF & & & $\begin{array}{l}7.024 * \\
(2.842)\end{array}$ \\
\hline Year*FCS to FBS & & & $\begin{array}{c}8.257 \\
(6.776)\end{array}$ \\
\hline Year*DI-NF to DI-FB & & & $\begin{array}{c}23.318 * * * \\
(6.217)\end{array}$ \\
\hline Year*DII-FB to DI-FB & & & $\begin{array}{l}11.255 \\
(6.776)\end{array}$ \\
\hline Year*DII-NF to DI-NF & & & $\begin{array}{c}15.886 * * \\
(5.612)\end{array}$ \\
\hline Constant & $\begin{array}{c}204.751 * * * \\
(14.505)\end{array}$ & $\begin{array}{c}203.120 * * * \\
(14.633)\end{array}$ & $\begin{array}{c}136.173 * * * \\
(21.338)\end{array}$ \\
\hline Covariance slope/intercept & .22 & .22 & .16 \\
\hline Observations & 2668 & 2668 & 2668 \\
\hline
\end{tabular}

Abbreviations: DI-NF = Division I with no football; DII-FB = Division II with football; DII-NF = Division II with no football; DI-FB = Division I with football; FBS = Football Bowl Subdivision; FCS $=$ Football Championship Subdivision; FTE $=$ full-time equivalent.

Note. Standard errors in parentheses. Omitted group: FBS. ${ }^{*} p<.05, * * p<.01,{ }^{*} * * p<.001$.

We see that in several instances the model-implied starting value of athletics fees per FTE is significantly different for universities at different affiliation levels. Athletics fees per FTE at FCS and DI-no football universities started out significantly higher than athletics fees per FTE at FBS universities. Universities 
that started at DII-no football and transitioned to DI-no football also had significantly higher starting levels of athletics fees per FTE than FBS universities. These coefficients largely suggest that the model-implied starting value of athletics fees per FTE were lowest at FBS universities.

The coefficients for the interaction terms in column 3 of Table 5 suggest that athletics fees per FTE not only started out lower, but also increased slower at FBS universities relative to many other types of NCAA universities. Each of the interaction terms were positive and three of the six were statistically significant. While athletics fees per FTE grow at a rate of just over \$2 per year at FBS universities, the growth trajectory was \$7 per year at DI-no football universities, \$23 per year at universities which transition from DI-no football to DI football, and \$16 per year at universities which transitioned from DII-no football to DI-no football. The covariance statistics reported in Table 5 are positive but rather weak. Figure 2 graphs the growth curves of athletics fees per FTE by NCAA subdivision affiliation.

\section{Growth Trajectory of Athletics Fees as Percentage of Costs per FTE}

Table 6 displays findings estimating the growth curve of per-student athletics fees as a percentage of overall student costs. Earlier we noted that we calculated this variable by dividing institutional net tuition and fee revenue by the FTE of a

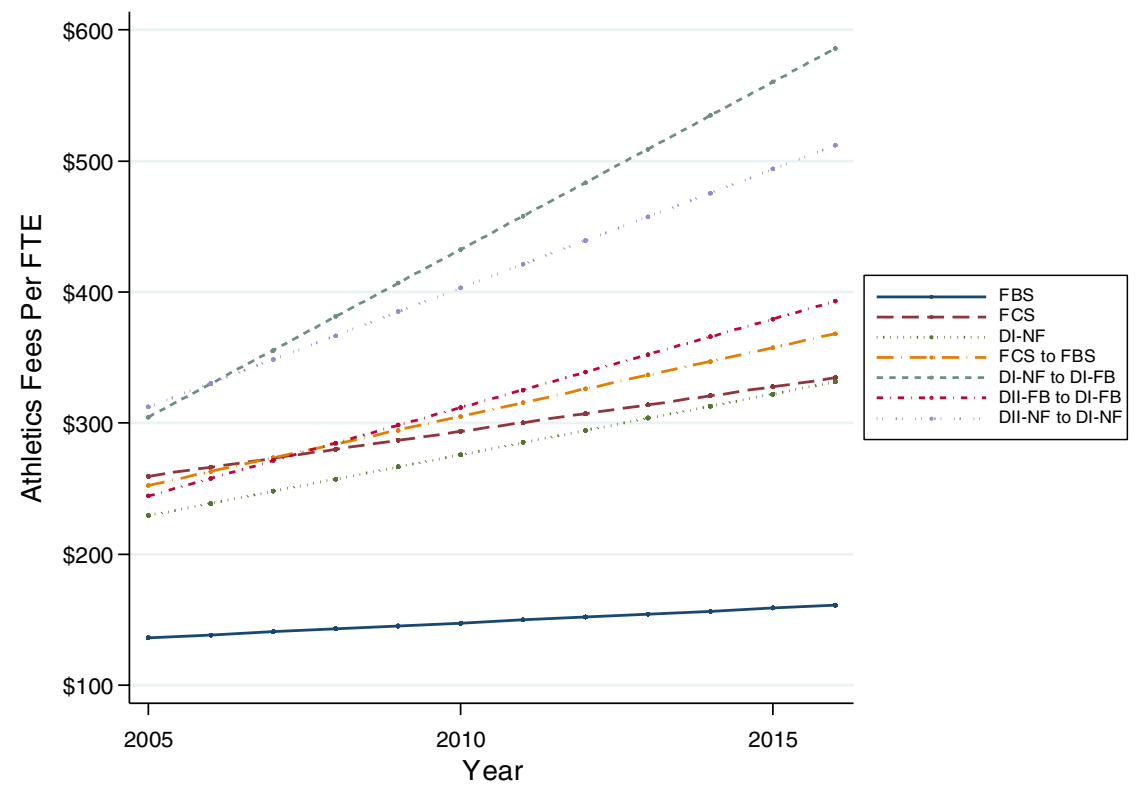

Figure 2 - Growth curves of athletics fees per full-time equivalent (FTE) by NCAA subdivision affiliation. Abbreviations: DI-NF = Division I with no football; DII-FB = Division II with football; DII-NF = Division II with no football; DI-FB = Division I with football; FBS $=$ Football Bowl Subdivision; FCS $=$ Football Championship Subdivision. 


\section{Table 6 Growth Trajectory of Athletics Fees as Percentage of Costs}

\begin{tabular}{|c|c|c|c|}
\hline Year & $\begin{array}{c}0.0002 \\
(0.0002)\end{array}$ & $\begin{array}{c}0.0014 * * * \\
(0.0004)\end{array}$ & $\begin{array}{l}0.0009 * \\
(0.0004)\end{array}$ \\
\hline Year squared & & $\begin{array}{c}-0.0001 * * * \\
(0.0000)\end{array}$ & $\begin{array}{c}-0.0001 * * * \\
(0.0000)\end{array}$ \\
\hline FCS & & & $\begin{array}{c}0.0324 * * * \\
(0.0075)\end{array}$ \\
\hline DI-NF & & & $\begin{array}{c}0.0253 * * \\
(0.0089)\end{array}$ \\
\hline FCS to FBS & & & $\begin{array}{c}0.0357 \\
(0.0215)\end{array}$ \\
\hline DI-NF to DI-FB & & & $\begin{array}{l}0.0479 * \\
(0.0197)\end{array}$ \\
\hline DII-FB to DI-FB & & & $\begin{array}{c}0.0280 \\
(0.0215)\end{array}$ \\
\hline DII-NF to DI-NF & & & $\begin{array}{c}0.0661 * * * \\
(0.0175)\end{array}$ \\
\hline Year*FCS & & & $\begin{array}{c}0.0006 \\
(0.0005)\end{array}$ \\
\hline Year* DI-NF & & & $\begin{array}{l}0.0015^{*} \\
(0.0006)\end{array}$ \\
\hline Year*FCS to FBS & & & $\begin{array}{c}0.0002 \\
(0.0015)\end{array}$ \\
\hline Year*DI-NF to DI-FB & & & $\begin{array}{c}0.0024 \\
(0.0013)\end{array}$ \\
\hline Year*DII-FB to DI-FB & & & $\begin{array}{c}0.0013 \\
(0.0015)\end{array}$ \\
\hline Year*DII-NF to DI-NF & & & $\begin{array}{c}0.0013 \\
(0.0012)\end{array}$ \\
\hline Constant & $\begin{array}{c}0.0454 * * * \\
(0.0033)\end{array}$ & $\begin{array}{c}0.0434 * * * \\
(0.0034)\end{array}$ & $\begin{array}{c}0.0245 * * * \\
(0.0048)\end{array}$ \\
\hline Covariance slope/intercept & .20 & .19 & .15 \\
\hline Observations & 2667 & 2667 & 2667 \\
\hline
\end{tabular}

Abbreviations: DI-NF = Division I with no football; DII-FB = Division II with football; DII-NF = Division II with no football; DI-FB = Division I with football; FBS = Football Bowl Subdivision; FCS $=$ Football Championship Subdivision .

Note. Standard errors in parentheses. Omitted group: FBS. ${ }^{*} p<.05,{ }^{*} p<.01,{ }^{* * *} p<.001$.

university to get a measure of student costs per FTE. We then divided athletics fees per FTE by student costs per FTE.

The findings from the unconditional model (column 1) show that the modelimplied initial value of athletics fees as percentage of costs per FTE was 4.5\%. In 
other words, athletics fees made up about 4.5\% of student costs in AY 2004-2005 among public NCAA Division I universities. The growth trajectory coefficient in the unconditional model was statistically insignificant. After inspecting the data, however, it was clear that the statistically insignificant growth coefficient was because athletics fees as a percentage of costs per FTE displayed a very nonlinear pattern. Once a quadratic term was added to the GCM (see column 2), we were able to obtain a more accurate measure of the growth in athletics fees as a percentage of costs. Similar to earlier findings on total athletics fees, the data suggest that while athletics fees as a percentage of costs increased over the time period studied, the rate of growth declined significantly.

In column 3 of Table 6, we see how NCAA affiliation played a role in the model-implied starting value and growth trajectory of athletics fees as a percentage of costs. Four of six NCAA affiliation categories had statistically significant larger percentages than FBS universities. Athletics fees as a percentage of costs appear to be lowest at FBS universities relative to other NCAA affiliation groups at the start of our data. The growth trajectories of athletics fees as a percentage of costs were rather homogenous across NCAA affiliation groups. Only one interaction term in column 3 was statistically significant, which tells us that percentage growth among DI-no football universities was significantly higher than growth among FBS universities. Growth curves of athletics fees as a percentage of costs per FTE by NCAA affiliation group is presented in Figure 3.

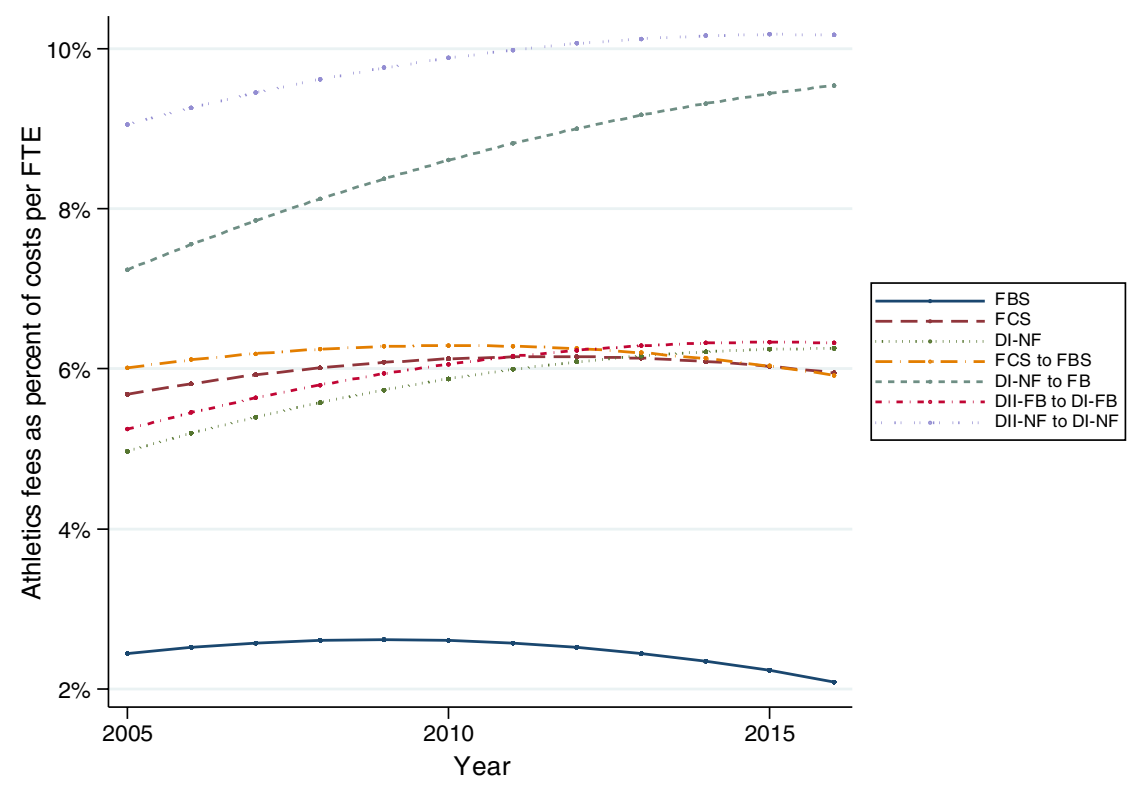

Figure 3 - Growth curves of athletics fees as percentage of costs by NCAA subdivision affiliation. Abbreviations: DI-NF $=$ Division I with no football; DII-FB = Division II with football; DII-NF = Division II with no football; DI-FB = Division I with football; FBS = Football Bowl Subdivision; FCS $=$ Football Championship Subdivision. 


\section{Discussion}

The goal of this study was to estimate the growth trajectory of mandatory athletics fees among public NCAA Division I universities. While previous empirical scholarship and newspaper articles have discussed various aspects of athletics fees, there remained a need for further research in this area. This study makes several important contributions to our understanding of athletics fees. Our study provides a more accurate portrayal of the growth of athletics fees over the past decade. We contend that a general assumption in much of the popular press on athletics fees is that these fees have seen a consistent linear increase (Rosenstein, 2017; Watkins, 2016). That assumption, however, had not yet been empirically tested using methods designed to detect latent growth curves. Our study, therefore, helps those interested in the economics of college athletics to engage in more accurate conversations about the growth of athletics fees.

Our study also offers a more nuanced analysis of athletics fees. We explore two important measures of the real cost of athletics fees. Total athletics fee data presented in USA Today is often used in the popular press to highlight how much students are asked to support athletics. To capture the real cost burden on individual students, however, we must examine how much each student at an institution is asked to contribute to athletics fees. In the few news articles which have looked at per-student athletics fees, the focus has been on one or two institutions which appear to have extraordinarily high athletics fees. By looking at per FTE athletics fees across a variety of institutions, this study provides a more accurate and more generalizable summary of how much individual students are being asked to contribute to athletics budgets and how much that contribution has grown.

The second measure of real costs we examined was athletics fees as a percentage of student costs. In our literature review we did not find any articles which examined what proportion of student costs was attributable to athletics fees. This information is critical to gaining a true understanding of the role athletics fees play in overall student costs relative to tuition and other fees such as room, board, or program-specific academic fees. Our study is among the first to explore how much of the student costs burden can be directly attributed to athletics fees and how much that burden has grown.

Our findings confirm that athletics fees among public NCAA Division I institutions have increased since AY 2004-2005. This positive growth trajectory, however, has not been consistently linear. Our findings suggest that the rate of growth for total athletics fees and athletics fees as a percentage of student costs has experienced a statistically significant decline in recent years. There are a number of potential explanations for this finding. The declining rate of growth might be a sign that universities are attempting to limit the amount of student fees used to support athletics. As knowledge of institutional athletics support has increased, universities are facing pressure to ensure that students are not being asked to shoulder these costs. This pressure might be impacting institutional pricing policies. Indeed, some universities such as Kansas State University and the University of Kansas have recently phased out or greatly reduced mandatory athletics fees (Dodd, 2014; Hobson \& Rich, 2015b). Purdue University President Mitch Daniels recently said, "a very small percentage ... of our students can actually make it on to an 
intercollegiate team .... and I don't think it's right to tax the ninety-eight percent who won't be able to play, many of whom aren't that interested, to support the (athletic) program. So we draw that line here" (Rosenstein, 2017, para. 23). Our findings might serve as an indicator that public NCAA Division I universities are in the process of limiting the amount of athletics fees students are charged. This does not mean, however, that institutional revenue allocations to athletics are decreasing. It may be that universities are allocating more tuition and general fund money to athletics as opposed to including specific athletics fees.

Our findings also tell a somewhat surprising story about the role of athletics fees in the overall cost of college. Institutional spending on auxiliary enterprises such as athletics are heavily scrutinized as a driver of the increasing cost of a college education (Armstrong \& Hamilton, 2013). At the average institution in this dataset, however, only $4.7 \%$ of student costs is attributable directly to athletics fees. At the median institution that percentage is $3.1 \%$. These percentages are relatively modest and suggest that athletics fees are a small portion of student costs at most public NCAA Division I institutions. Our findings are similar to those of Kelchen (2016), who found institutional athletics spending to have no relationship with student fee levels. Policy makers, such as those mentioned earlier in Virginia and Georgia, seeking to limit institutions' ability to charge athletics fees might find that their efforts will have little real impact on overall college costs.

The positive covariance between the intercept variance and the slope variance in our estimation models might be indicative of the increased revenue available to universities which already generate high amounts of athletics revenue. Since 2004, television deals, licensing/endorsement deals, and big spending donors have meant that athletics departments are earning more money than ever before (Hobson \& Rich, 2015a). This increased revenue, however, has been largely concentrated at universities with already high levels of athletics revenue. As college athletics expenses continued to rise and revenues continued to be concentrated in select universities over the time period looked at in this study, it is likely that universities with already low athletics fees had no need to increase them while universities with initially higher athletics fees were forced to charge students even more. The covariances from this study would support this story, but more research on the progenitors of athletics fee increases should be done before we can say with confidence that our hypothesis is accurate.

A key finding of this study is that athletics fees often differed significantly based on NCAA affiliation category. When looking at per-FTE athletics fees and athletics fees as percentage of costs, FBS universities had, by far, the lowest athletics fees. This was not surprising given that many FBS universities generate a significant amount of revenue from athletics. All of the 24 universities which earn enough generated revenue to cover athletics expenses are members of the FBS (Brady, Berkowitz, \& Schnaars, 2015). The presence of these institutions is likely driving the lower FBS athletics fees we found in this study. Our findings also support the NCAA report on athletics finances (Fulks, 2015) which shows that allocated institutional revenue to athletics at FBS universities is lower than allocated institutional revenue to athletics at other NCAA affiliation levels. While FBS universities often get the headlines when it comes to athletics fees, our study suggests that individuals concerned with rising athletics fees should focus their attention on other NCAA Division I subdivisions. 
An interesting story told by our growth curve analysis relates to athletics fees among those institutions that transitioned into Division I or within Division I. Many institutions of higher education see athletics as a way to increase the prestige, reputation, and notoriety of their school (Art \& Science Group, 2011). As a result, a number of universities have transitioned into "higher" tier athletics by adding a football program, moving from NCAA Division II to Division I, or moving their football program from the FCS to the FBS. These types of transitions can be very expensive (Loh, 2015; Wolverton et al., 2015), and we expected to see these expenses play out in our data analysis. We did, in some instances, see that universities which transitioned had higher levels of athletics fees. For example, the growth trajectory of total athletics fees at universities which transitioned from FCS to FBS and for Division I universities which added a football program were significantly higher relative to FBS universities. With regard to per-FTE athletics fees, we found that Division I universities which added a football program and universities that transitioned from Division II to Division I had significantly larger growth trajectories than FBS universities. For the most part, however, the findings related to transition universities were rather inconsistent with regard to how they differed from FBS universities. Most model-implied initial values and growth trajectory coefficients showed transition universities were not significantly different than FBS universities. We believe this might be due to our empirical modeling decisions. Our estimation strategy did not attempt to specifically model the impact of transition on athletics fees given that we treated this transition as a time-invariant variable. Therefore, we may not have fully captured how transitioning into or within Division I impacts athletics fees. Also, the number of institutions with changes in NCAA divisional affiliation was relatively small. Therefore, the statistical power with regard to these categories may not have been sufficiently large.

\section{Limitations and Future Research}

Important data limitations of this study must be noted. Some argue that data in the USA Today College Athletics Finance Database can be misleading and inaccurate due to differences in accounting practices across colleges and universities (Dosh, 2013; Wunderlich, 2013). Some universities may indeed operationalize athletics fees differently than other universities. It is also possible that a university's method of accounting or reporting athletics fee data could vary from year to year because of personnel changes. While we have no evidence to suggest data in the USA Today College Athletics Finance database is flawed, we acknowledge the potential data validity concerns.

The generalizability of this study is also limited. The data used in this study came from public NCAA Division I universities. Generalizing these findings to private universities or public non-NCAA Division I universities should only be done with extreme caution. We also note that some public NCAA Division I universities (such as San Diego State University, West Virginia University, and University of Pittsburgh) do not provided data to the USA Today College Athletics Finance Database. If these schools are systematically different than other public NCAA Division I universities with regard to athletics fees, our generalizations 
about these universities might be biased. We encourage higher education institutions and college athletics governing bodies to make institutional-level athletics fees data from a wider variety of colleges and universities available to researchers. This would allow for broader cross-institutional analysis of athletics fees and the role these fees play in college costs.

There are several avenues for future research which would further expand our understanding of student fees. While our study grouped all FBS-only universities into one category, there are often significant financial differences between FBS universities in "Power 5 Conferences" and FBS universities in "Group of 5 Conferences." Growth curve analysis within the FBS, with controls for conference affiliation, would provide an interesting look at within-FBS variation in athletics fees growth.

Growth curve models with time-invariant and time-variant covariates should also be considered in future work on the growth of athletics fees. Our study only included one time-invariant covariate as a predictor of growth trajectory. Several other covariates related to institutional type, location, student body composition, endowment, and more could be used in future model estimations. One particularly interesting idea would be a multivariate growth curve model of the growth of athletics fees and direct institutional allocations to athletics simultaneously. This would allow for the calculation of a covariance between the growth of two major types of allocation revenue to explore whether institutions have replaced one form of athletics revenue with another over time. A multivariate growth curve model would allow us to answer whether universities that have higher growth trajectories in athletics fees simultaneously have lower growth trajectories in direct institutional support to athletics.

\section{Conclusion}

Mandatory athletics fees are becoming an important part of larger policy discussions related to college costs. Many conversations about athletics fees, however, are grounded in conjecture and anecdotal evidence. Our study looked to provide an empirically-based analysis of the growth in athletics fees from 2004-2016 at public NCAA Division I universities. We hope this study spawns more scholarship that eventually leads to a more valid picture of the role athletics fees play in overall student costs.

\section{Note}

1. For estimations of the nonlinear growth trajectory of student fees, the quadratic term was added to the level 1 regression equation while the time-invariant covariate was introduced in level 2 equations. The time-by-affiliation interaction is a cross-level interaction. For more information on estimating GCM, please see Rabe-Hesketh and Skrondal (2008).

\section{References}

Armstrong, E.A., \& Hamilton, L.T. (2013). Paying for the party. Cambridge, MA: Harvard University Press. 
Art \& Science Group. (2011). Quantitative and qualitative research with football bowl subdivision university presidents on the costs and financing of intercollegiate athletics: Report of findings and implications. Retrieved from http://www. knightcommissionmedia.org/images/President_Survey_FINAL.pdf

Berkowitz, S., Upton, J., McCarthy, M., \& Gillum, J. (2010, September 21). How student fees boost college sports amid rising budgets. USA Today. Retrieved from http://www. usatoday.com/sports/college/2010-09-21-student-fees-boost-college-sports_N.htm

Brady, E., Berkowitz, S., \& Schnaars, C. (2015, May 26). College athletics finance report: Non-power 5 schools face huge money pressure. USA Today. Retrieved from https:// www.usatoday.com/story/sports/college/2015/05/26/ncaa-athletic-finances-revenueexpense-division-i/27971457/

Denhart, M., \& Ridpath, D. (2011). Funding the arms race: A case study of student athletic fees. Washington, DC: Center for College Affordability and Productivity. Retrieved from http://www.centerforcollegeaffordability.org/uploads/Funding_the_Arms_Race. pdf

Denhart, M., \& Vedder, R. (2010). Intercollegiate athletics subsidies: A regressive tax. Washington, DC: Center for College Affordability and Productivity. Retrieved from https://files.eric.ed.gov/fulltext/ED536486.pdf

Dodd, R. (2014, August 3). Even as college athletic department revenues rise, student subsidies remain. The Kansas City Star. Retrieved from http://www.kansascity.com/ sports/college/article984117.html

Dosh, K. (2013). Saturday millionaires: How winning football builds winning colleges. New York, NY: Wiley.

Evans, J.D. (1996). Straightforward statistics for the behavioral sciences. Pacific Grove, CA: Brooks/Cole Publishing.

Fulks, D. (2015). NCAA division I intercollegiate athletics programs report. Indianapolis, IN: NCAA. Retrieved from https://www.ncaa.org/sites/default/files/2015\%20Division $\% 201 \% 20$ RE\%20report.pdf

Hobson, W., \& Rich, S. (2015a, November 23). Playing in the red. The Washington Post. Retrieved from http://www.washingtonpost.com/sf/sports/wp/2015/11/23/running-upthe-bills/

Hobson, W., \& Rich, S. (2015b, November 30). Why students foot the bill for college sports, and how some are fighting back. The Washington Post. Retrieved from https://www. washingtonpost.com/sports/why-students-foot-the-bill-for-college-sports-and-howsome-are-fighting-back/2015/11/30/7ca47476-8d3e-11e5-ae1f-af46b7df8483_story. html?utm_term=.9cc1594db5a9

Howard, M.L. (2016). Public goods generated by intercollegiate athletics: Student's willingness-to-pay increased athletic fees (PhD dissertation). Tallahassee, FL: The Florida State University.

Kearney, T.D. (2014). Three essays on intercollegiate athletics and the financial relationship with institutions of higher education. (Doctoral dissertation). Urbana, IL: University of Illinois at Urbana-Champaign.

Kelchen, R. (2016). An analysis of student fees: The roles of states and institutions. The Review of Higher Education, 39, 597-619. doi:10.1353/rhe.2016.0027

Kingkade, T. (2012, May 9). College sports expense: How much are students paying? HuffPost. Retrieved from https://www.huffingtonpost.com/2012/05/07/college-sportson-student-fees_n_1497376.html?slideshow=true

Kingkade, T. (2016, May 12). Georgia caps how much student fees can subsidize college sports. The Huffington Post. Retrieved from https://www.huffingtonpost.com/entry/ georgia-student-fees-cap-sports_us_5734aaffe4b08f96c1825fca

Lapan, T. (2016, September 13). College students begin to cry foul about paying more for sports. US News and World Reports. Retrieved from https://www.usnews.com/ 
news/articles/2016-09-13/so-long-banana-slugs-students-cry-foul-about-paying-morefor-sports

Loh, S. (2015, April 19). UCSD exploring move to division I... again. The San Diego Union-Tribune. Retrieved from http://www.sandiegouniontribune.com/sports/sdutucs-tritons-athletics-move-division-i-transition-2015apr19-story.html

Minium, H. (2015, March 31). Mcauliffe signs bill that limits athletic student fees. The Virginian-Pilot. Retrieved from https://pilotonline.com/sports/mcauliffe-signs-billthat-limits-athletic-student-fees/article_337e7bec-d46e-5e15-bba6-6fc8de3a5f01.html

Morton, J.T. (2017). Impact of student fees on winning in the NCAA. Journal of Contemporary Athletics, 11, 73-82.

Rabe-Hesketh, S., \& Skrondal, A. (2008). Multilevel and longitudinal modeling using stata. College Station, TX: STATA Press.

Ridpath, D., Smith, J., Garrett, D., \& Robe, J. (2015). Shaping policy and practice in intercollegiate athletics: A study of student perceptions of resource allocation for athletics and its effect on affordability of higher education. Journal of SPORT, 4.

Rosenstein, J. (2017, November 15). The athletic fee that isn't there. Except it is. The Huffington Post. Retrieved from https://www.huffingtonpost.com/entry/the-athleticfee-that-isnt-there-except-it-is_us_59f66443e4b05f0ade1b5848

Rudolph, M.J. (2017). Do intercollegiate athletics subsidies correlate with educational spending? An empirical study of public division-i colleges and universities. (Doctorial dissertation, University of Kentucky). Retrieved from http://uknowledge.uky.edu/ epe_etds/51/

Ryman, A. (2017, November 17). University of Arizona to spend $\$ 66 \mathrm{~m}$ to renovate football stadium, add facilities. The Arizona Republic. Retrieved from https://www.azcentral. com/story/news/local/arizona/2017/11/16/university-arizona-spend-66-million-footballstadium-upgrades-practice-facility/859975001/

Suggs, W. (2004, April 30). At some colleges, students tax themselves to pay for sports. The Chronicle of Higher Education. Retrieved from https://www.chronicle.com/article/AtSome-Colleges-Students-Tax/9219

Thelin, J.R. (2000). Good sports? Historical perspective on the political economy of intercollegiate athletics in the era of title ix, 1972-1997. The Journal of Higher Education, 71, 391-410. doi:10.1080/00221546.2000.11778842

Thelin, J.R., \& Wiseman, L.L. (1990). Fiscal fitness? The peculiar economics of intercollegiate athletics. Capital Ideas, 4, 2-12.

USA Today Sports. (2017, July 6). Methodology for 2016 NCAA athletic department revenue database. USA Today. Retrieved from http://sports.usatoday.com/2017/07/06/ methodology-for-2016-ncaa-athletic-department-revenue-database/

Watkins, M. (2016). Students pitching in more as texas universities' athletics costs climb. The Texas Tribune. Retrieved from https://www.texastribune.org/2016/03/18/texasuniversities-are-hiking-student-fees-support/

Wolverton, B., Hallman, B., Shifflett, S., \& Kambhampati, S. (2015, November 15). Sports at any cost: How college students are bankrolling the athletics arms race. Huffington Post. Retrieved from http://projects.huffingtonpost.com/ncaa/sports-at-any-cost

Wunderlich, D. (2013). Be careful with USA today's college finances database. Retrieved from http://www.teamspeedkills.com/2013/5/8/4311070/usa-today-college-financesdatabase-2012. 